\title{
A Change Would Do You Good ... An Experimental Study on How to Overcome Coordination Failure in Organizations On-line Appendices
}

\section{By Jordi Brandts and David J. Cooper}

Appendix B

\section{Additional Results}

This appendix gives additional details on the results reported in the paper. Tables B.1 through B.6 provide a complete record of every firm's outcome in every round. The tables are broken down by cell and include data from the two "corrupt" firms that contained subjects who had previously participated.

\section{(Insert Tables B.1 - B.6 here)}

B.1. Individual Level Results: Figures B.1 and B.2 are the employee-level data figures that parallel Figures 1 and 2 in the text. The employee-level data is consistent with Regularities 1 and 2. In particular, consider the data from rounds $26-30$ of Cell 5, the cell where the bonus rate is increased to $B=14$ and then returns to its original value of $B=6$. The effort levels are almost level over this time period, indicating a high degree of convergence. It seems unlikely that an extension of an additional ten rounds would change our conclusion that shock therapy persistently increases effort above its initial levels.

\section{(Insert Figures B.1 and B.2 here)}

\section{B.2 Cross-Country Comparisons: Figures B.3 and B.4 break down the data underlying}

Regularities 1 and 2 by country. Table B.7 reports the results of ordered probit regressions exploring whether Regularities 1 and 2 are robust to more detailed controls for location effects.

To simplify Figure B.3, we have pooled together data from Cells 2 and 3 (increases to B $=10$ and $\mathrm{B}=8$ respectively). This will also give us additional power when running regressions, 
an important issue since controlling more rigorously for location effects essentially cuts our data set in halves. The data graphed in Figure B.3 provides additional support for Regularity 1. In both locations, average minimum effort with an increase to $\mathrm{B}=14$ was at or below the average minimum effort with smaller increases. Note that only in the Cleveland data is performance with $\mathrm{B}=14$ substantially worse than with lower bonus rate increases, suggesting that this odd feature of the data may be an anomaly.

\section{(Insert Figure B.3 here)}

The left portion of Table B.7 reports ordered probit regressions corresponding to Figure B.3. The data set is the same as used for the regressions reported in Section V.B of the main text. We only report regressions here on firm level data. The base is data from Cell 6 , the cell with no increase in the bonus rate for rounds $11-20$. Note that the specification reported here differences the data with an increase to $B=14$ from the data with lower bonus rate increases. The parameter estimates of interest are "Barcelona*Rounds $16-20 *$ Bonus $=14$ " and “Cleveland*Rounds $16-20 *$ Bonus = 14." If effort levels responded monotonically to bonus rate increases in one of the locations, a positive (and ideally statistically significant) estimate should be observed. In both cases the estimated differences are negative, significantly so for the Cleveland data. These results are entirely consistent with Regularity 1.

\section{(Insert Table B.7 here)}

Figure B.4 is a complicated figure due to the large number of data cells involved. To somewhat simplify it, data from rounds $1-10$ with $B=6$ are not shown as separate plots as in

Figure 2. Instead, we include the average minimum effort for round 10 as the starting point for each plot. Figure B.4 provides additional support for Regularity 2. In particular, consider data 
from Cell 5. While the average minimum effort drops in both locations when the bonus rate returns to $\mathrm{B}=6$, in neither Barcelona nor Cleveland does it return to its original level.

\section{(Insert Figure B.4 here)}

The right portion of Table B.7 reports ordered probit regressions on firm-level data corresponding to Figure B.4. The data set is the same as used for the regressions reported in Section V.C of the main text The base is data from rounds $6-10$ for firms that have their bonus rate increased to $\mathrm{B}=14$. The important variables are "Barcelona*Rounds $26-30$, Bonus $=6,10$, or 14 " and "Cleveland*Rounds $26-30$, Bonus $=6,10$, or $14 . "$ If shock therapy is successful under the most difficult circumstance, a decrease of the bonus rate back to its original level of B $=6$, these parameter estimates should be positive and statistically significant. This is true for both locations even when the relatively conservative clustering approach is used to control firm effects, although these results should be interpreted with caution given the small number of clusters in the cells when the data is broken down by treatment and location. As much as is possible given our dataset, Regularity 2 receives additional support.

We don't claim that behavior is identical over the two locations. Coordination generally is somewhat easier to accomplish in the Cleveland firms. However, the main qualitative features of the data are quite similar over both locations. Our most important findings, Regularities 1 and 2, hold for data from both Cleveland and Barcelona.

B.3 Alternative Time Controls: Table B.8 reports regression results using an alternative specification to control for subjects' experience rather than the "blocks" approach used in the main text. Specifically, the variable we use is the number of rounds remaining in the current block of ten rounds. This specification may seem unnatural at first, but the point is to compare behavior at the end of the block rather than the beginning. 


\section{(Insert Table B.8 here)}

The left portion of Table B.8 reports ordered probit regressions corresponding to those reported in Table 4. The data set is the same as used for the regressions reported in Section V.B of the main text. We only report regressions here on firm level data. The base is data from Cell 6 , the cell with no increase in the bonus rate for rounds $11-20$. The critical variables are the three dummies for the three different bonus rate increases that occur in round $11-$ these dummies capture the final effect of the bonus rate increases. The results are consistent with the results reported in Table 4, as the long-term impact of increasing the bonus rate is nonmonotonic. Our support for Regularity 1 is robust to the use of alternative time controls. The left portion of Table B.8 reports ordered probit regressions corresponding to those reported in Table 5. The data set is the same as used for the regressions reported in Section V.C of the main text. We only report regressions here on firm level data. The base is data from rounds $6-10$ for firms that have their bonus rate increased to $B=14$. The critical variable is the dummy for rounds $21-30$. This dummy captures the difference between the end point for Cell 5 and the end point of the initial ten round block with $\mathrm{B}=6$. This variable is positive and statistically significant, indicating that shock therapy is effective. This result is consistent with the regressions reported in Table 5 - Regularity 2 is robust to the use of alternative time controls. 


\section{Appendix C}

\section{The EWA Model}

In this appendix we give a detailed description of the EWA model, describe in more detail how it was modified to incorporate change sensitivity, strategic teaching, and endogenous growth of strategic teaching, and report parameter estimates used for the simulations.

C.1 The Basic EWA Model: With one exception, details for the basic model are drawn verbatim from Colin Camerer and Teck-Hua Ho (1999) which should be read for a full understanding of the model. In each round t, two variables play a central role in determining a player's choices. The first is $\mathrm{N}(\mathrm{t})$, which can be interpreted as representing a player's effective level of experience. $\mathrm{N}(0)$ is an exogenous parameter which will be fitted from the data. The evolution of $N(t)$ for $t \geq$ 1 is then governed by $(\mathrm{C} 1)$, with $\rho$ being a positive constant.

$$
N(t)=\rho \cdot N(t-1)+1
$$

The second central set of variables is the player's attractions for the available strategies. Let $A_{i}^{j}(t)$ be player $i$ 's attraction for his $\mathrm{j}^{\text {th }}$ strategy in round $\mathrm{t}$. Initial attractions, $A_{i}^{j}(0)$, are exogenous parameters that will be fitted from the data. The equation for updating attractions is then given by $(\mathrm{C} 2)$. The parameter $\varphi$ can be interpreted as representing the rate at which past attractions are forgotten while $\delta$ is the weight on "imagined" payoffs - the payoffs the player would have received if a different strategy had been selected. The function $I\left(s_{i}^{j}, s_{i}(t)\right)$ is an indicator function which equals 1 if player i selects his $\mathrm{j}^{\text {th }}$ strategy in round $\mathrm{t}$ and 0 otherwise.

$$
A_{i}^{j}(t)=\frac{\phi \cdot N(t-1) \cdot A_{i}^{j}(t-1)+\left[\delta+(1-\delta) \cdot I\left(s_{i}^{j}, s_{i}(t)\right)\right] \cdot \pi_{i}\left(s_{i}^{j}, s_{-i}(t)\right)}{N(t)}
$$

Once attractions have been determined, choice probabilities are given by a logit rule as displayed in (C3). Let $P_{i}^{j}(t)$ be the probability that player $\mathrm{i}$ chooses his $\mathrm{j}^{\text {th }}$ strategy in round $\mathrm{t}$. 
The parameter $\lambda$ gives the sensitivity of choices to the relative size of attractions. If $\lambda=0$, choices are uniformly distributed over all strategies regardless of previous experiences; as $\lambda \rightarrow \infty$ the choice function selects the strategy with the highest attraction almost certainly.

$$
P_{i}^{j}(t)=\frac{e^{\lambda \cdot P_{i}^{j}(t-1)}}{\sum_{k=1}^{m_{i}} e^{\lambda \cdot P_{i}^{k}(t-1)}}
$$

Our sole departure from Camerer and Ho's basic model is the inclusion of a reset parameter $\mathrm{r}_{10}$. This parameter determines the weight put on old attractions following the reset at the end of the first ten round block. Let $\tilde{A}_{i}^{j}(10)$ be player i's attraction for his $j^{\text {th }}$ strategy following the reset.

$$
\tilde{A}_{i}^{j}(10)=r_{10} \cdot A_{i}^{j}(10)+\left(1-r_{10}\right) \cdot A_{i}^{j}(0)
$$

The parameters for the basic EWA model were fit from data for rounds $1-10$ of Cells 1 -5 and rounds $1-20$ of Cell 6 via standard maximum likelihood techniques. The resulting estimates along with standard errors are displayed in the first column of Table C.1. Note that a number of the parameters have been rescaled to allow for better convergence. Additionally, the model does not allow for heterogeneity among individuals - e.g. the parameter values used by all players are identical. ${ }^{1}$ We have also fit a two segment model like that presented in Camerer and Ho (1999) to the data and find that this fails to improve the model's performance.

\section{(Insert Table C.1 here)}

C.2 Modifications to the EWA Model: We make three substantive modification to the basic model of Camerer and Ho (1999). The first is the inclusion of change sensitivity. While similar in spirit to the change detector of Camerer, Juin-Kuan Chong, and Ho (2002), a somewhat different functional form is used. This does not reflect any deep theoretical point, but instead derives from our experimentation with various functional forms. The simple form described 
below was easily our most successful attempt at improving the model's fit to the data. In round $t$, let $c_{i}(t)$ be the sum of the changes in other player's efforts observed by player $i$ in round $t^{2}$ Given that this is undefined in round 1 , by default $\mathrm{c}_{\mathrm{i}}(1)=0$. Let $\sigma\left(\mathrm{c}_{\mathrm{i}}(\mathrm{t})\right)$ be an indicator variable which equals 1 if $\mathrm{c}_{\mathrm{i}}(\mathrm{t})>0$. The updating rule given by $(\mathrm{C} 2)$ is altered to (C5). The change sensitivity depends on the sign of the observed change in others' efforts; the parameters $\mathrm{C}^{+}$and $\mathrm{C}^{-}$give the additional weight put on the most recent experience as a function of, respectively, a positive or a negative change in the sum of others' efforts. As will be seen, this asymmetry plays an important role in fitting the data.

$A_{i}^{j}(t)=\frac{\phi \cdot N(t-1) \cdot A_{i}^{j}(t-1)+\left(1+\left(C^{+} \cdot \sigma\left(c_{i}(t)\right)+C^{-} \cdot\left(1-\sigma\left(c_{i}(t)\right)\right)\right) \cdot c_{i}(t)\right) \cdot\left[\delta+(1-\delta) \cdot I\left(s_{i}^{j}, s_{i}(t)\right)\right] \cdot \pi_{i}\left(s_{i}^{j}, s_{-i}(t)\right)}{N(t)}$

Our second major modification is the inclusion of "strategic teaching." This is in the spirit of strategic teaching as introduced by Camerer, Ho, and Chong (2002) as well as related models due to Dale O. Stahl (1999) and Cooper and John H. Kagel (2004). A strategic teacher anticipates that other players are learning over time. Entering period t, a strategic teacher has calculated attractions through round $t-1$ like any other player. He then uses (A3) to estimate the likelihood of each possible combination of three effort levels being chosen by the other three players. $^{3}$ Based on these estimates, he calculates an expected payoff in round $t$ for each of his available strategies. He then also calculates a forward payoff for each available strategy. Specifically, new attractions entering round $t+1$ are calculated for each of the other three players. This is used to generate expected payoffs for each of the strategic teacher's strategies in round $t+1$. An expected forward payoff is then calculated for round $t+1$ assuming the strategic teacher's action in round $t+1$ is chosen by the same logit rule used to select his action in round $\mathrm{t}^{4}{ }^{4}$ The strategic teacher's "true" attraction for strategy $\mathrm{j}$ in round $\mathrm{t}$ is then given by a weighted 
average of its expected payoff in round $t$ and its expected forward payoff for round $t+1$, with the weight on the round t expected payoff normalized to 1 and the weight of the forward payoff, $\mathrm{w}_{\mathrm{F}}$, being fit from the data. An action for round $t$ is selected using a logit rule as shown in (C3), although the sensitivity is not required to be the same as that used by basic EWA types.

Intuitively, strategic teachers are noisy best responders to basic EWA learners with a correction for the current round's effect on the future actions of others. Several features of this model are worth noting. First, strategic teachers are quite sophisticated. Not only are they bestresponding to current actions, albeit noisily, but they also anticipate the impact of their choices on others' future actions. Second, strategic teachers only look a very short distance (one round) into the future. This short horizon is dictated by the extreme computational complexity of the model. A longer horizon would presumably lead to strategic teachers responding more strongly to a change in the bonus rate and therefore might improve the model's performance (although the lack of responsive leaders would still not be addressed). Finally, unlike the model introduced by Camerer, Ho, and Chong (2002), strategic teachers assume that no other players are strategic teachers. This assumption of myopia is again driven by the need to make the model less computationally demanding. If it is relaxed by having strategic teachers put positive probability on others being strategic teachers, the result would be more strong leaders in the simulations.

The final modification to the model is endogenous growth of strategic teachers. For each basic EWA learner in round t, the probability $p_{i}^{S}(t)$ of switching to be a strategic teacher in round $t+1$ is given by (C6). Note that it is only possible for a basic EWA learner to become a strategic teacher when a positive change in effort has been observed.

$$
p_{i}^{S}(t)=p_{j u m p} \cdot c_{i}(t) \cdot \operatorname{sign}\left(c_{i}(t)\right)
$$


The parameters for the modified model were fit from data for rounds $1-10$ of Cells $1-5$ and rounds $1-20$ of Cell 6 via standard maximum likelihood techniques. The resulting estimates along with standard errors are displayed in the second column of Table C.1. Note that $p_{\text {reset }}$ was not fit from the data, but instead was chosen via a rough visual calibration. ${ }^{5}$ Also recall that the fitted value of the reset parameter was doubled for simulations of cells where the bonus rate was increased for rounds $11-20$.

It may seem odd that the estimated value of $\mathrm{C}^{+}$is negative and statistically significant. This result is driven by the presence of responsive followers in the data. To emulate responsive followers, the estimation needs to generate a higher likelihood of an increase in effort following large increases by others. However, the best response usually hasn't changed in these cases as there is typically more than one laggard. By making $\mathrm{C}^{+}$negative, the model actually puts less weight on this "bad" outcome and makes it more likely that random experimentation will move the player to a good outcome. This is another example of how difficult it is for the EWA model to capture the behavior of responsive followers. 
${ }^{1}$ See Nathaniel T. Wilcox (2003) for a discussion of the impact of heterogeneity on estimates of EWA parameters.

${ }^{2}$ The use of the sum of changes makes it unnecessary for players to be able to identify which of the other players is responsible for a specific choice, information which is unavailable in our experimental design.

${ }^{3}$ Note that these calculations rely solely on the strategic teacher's own attractions - in other words, only his own experiences are used. Since he cannot identify which actions belong to which players, a strategic teacher in our experiment cannot possibly calculate the attractions of other players.

${ }^{4}$ This implicitly assumes that the choice in round $t+1$ is noisier as no forward payoff is being included in the player's choice function for this future decision.

${ }^{5}$ Fitting $\mathrm{p}_{\text {reset }}$ makes the already enormous computation complexity of the model almost unworkable. 
Table B.1

Firm by Firm Summaries, Cell $1(B=6 / B=14 / B=14)$

\begin{tabular}{|c|c|c|c|c|c|c|c|c|c|c|}
\hline Firm & 1 & 2 & 3 & 4 & 5 & 6 & 7 & 8 & 9 & 10 \\
\hline Barcelona & 0 & 0 & 0 & 0 & 0 & 1 & 1 & 1 & 1 & 1 \\
\hline Corrupt & 0 & 0 & 0 & 0 & 0 & 0 & 0 & 0 & 0 & 0 \\
\hline \multicolumn{11}{|l|}{ Round } \\
\hline 1 & 0 & 10 & 10 & 0 & 30 & 0 & 10 & 0 & 0 & 40 \\
\hline 2 & 0 & 0 & 10 & 0 & 40 & 10 & 10 & 0 & 0 & 40 \\
\hline 3 & 0 & 0 & 10 & 0 & 40 & 20 & 0 & 0 & 0 & 40 \\
\hline 4 & 0 & 0 & 10 & 0 & 40 & 10 & 0 & 0 & 0 & 40 \\
\hline 5 & 0 & 0 & 0 & 0 & 20 & 10 & 0 & 0 & 0 & 40 \\
\hline 6 & 0 & 0 & 0 & 0 & 40 & 10 & 0 & 0 & 0 & 40 \\
\hline 7 & 0 & 0 & 0 & 0 & 40 & 10 & 0 & 0 & 0 & 40 \\
\hline 8 & 0 & 0 & 0 & 0 & 40 & 10 & 0 & 0 & 0 & 40 \\
\hline 9 & 0 & 0 & 0 & 0 & 40 & 10 & 0 & 0 & 0 & 40 \\
\hline 10 & 0 & 0 & 0 & 0 & 40 & 10 & 0 & 0 & 0 & 40 \\
\hline 11 & 0 & 10 & 10 & 0 & 40 & 10 & 10 & 40 & 40 & 40 \\
\hline 12 & 0 & 10 & 10 & 30 & 40 & 20 & 0 & 40 & 40 & 40 \\
\hline 13 & 0 & 10 & 10 & 40 & 40 & 30 & 0 & 40 & 40 & 40 \\
\hline 14 & 0 & 20 & 10 & 40 & 40 & 30 & 0 & 40 & 0 & 40 \\
\hline 15 & 0 & 20 & 10 & 40 & 40 & 30 & 0 & 40 & 0 & 40 \\
\hline 16 & 0 & 30 & 10 & 40 & 40 & 30 & 0 & 40 & 0 & 40 \\
\hline 17 & 0 & 40 & 10 & 40 & 40 & 30 & 0 & 40 & 0 & 40 \\
\hline 18 & 0 & 40 & 10 & 40 & 40 & 30 & 0 & 40 & 0 & 40 \\
\hline 19 & 0 & 30 & 10 & 40 & 40 & 30 & 0 & 40 & 0 & 40 \\
\hline 20 & 0 & 30 & 10 & 40 & 40 & 30 & 0 & 40 & 0 & 40 \\
\hline 21 & 0 & 20 & 10 & 40 & 40 & 30 & 10 & 40 & 40 & 40 \\
\hline 22 & 0 & 20 & 10 & 40 & 40 & 30 & 0 & 40 & 40 & 40 \\
\hline 23 & 0 & 20 & 10 & 40 & 40 & 30 & 0 & 40 & 0 & 40 \\
\hline 24 & 0 & 20 & 10 & 40 & 40 & 30 & 0 & 40 & 0 & 40 \\
\hline 25 & 0 & 20 & 10 & 40 & 40 & 30 & 0 & 40 & 0 & 40 \\
\hline 26 & 0 & 20 & 10 & 40 & 40 & 30 & 0 & 40 & 0 & 40 \\
\hline 27 & 0 & 20 & 10 & 40 & 40 & 30 & 0 & 40 & 0 & 40 \\
\hline 28 & 0 & 20 & 10 & 40 & 40 & 30 & 0 & 40 & 0 & 40 \\
\hline 29 & 0 & 20 & 10 & 40 & 40 & 30 & 0 & 40 & 0 & 40 \\
\hline 30 & 0 & & 10 & 40 & 40 & & & & 0 & 30 \\
\hline
\end{tabular}


Table B.2

Firm by Firm Summaries, Cell $2(B=6 / \mathrm{B}=10 / \mathrm{B}=10)$

\begin{tabular}{|c|c|c|c|c|c|c|c|c|c|c|}
\hline Firm & 11 & 12 & 13 & 14 & 15 & 16 & 17 & 18 & 19 & 20 \\
\hline Barcelona & 0 & 0 & 0 & 0 & 0 & 1 & 1 & 1 & 1 & 1 \\
\hline Corrupt & 0 & 0 & 0 & 0 & 0 & 0 & 0 & 0 & 0 & 1 \\
\hline \multicolumn{11}{|l|}{ Round } \\
\hline 1 & 0 & 0 & 0 & 10 & 20 & 20 & 0 & 0 & 0 & 40 \\
\hline 2 & 0 & 0 & 0 & 10 & 20 & 0 & 0 & 0 & 0 & 40 \\
\hline 3 & 0 & 0 & 0 & 0 & 20 & 10 & 0 & 0 & 0 & 40 \\
\hline 4 & 0 & 0 & 0 & 10 & 30 & 0 & 0 & 0 & 0 & 40 \\
\hline 5 & 0 & 0 & 0 & 0 & 30 & 10 & 0 & 0 & 0 & 30 \\
\hline 6 & 0 & 0 & 0 & 0 & 30 & 0 & 0 & 0 & 0 & 30 \\
\hline 7 & 0 & 0 & 0 & 0 & 30 & 0 & 0 & 0 & 0 & 30 \\
\hline 8 & 0 & 0 & 0 & 0 & 30 & 0 & 0 & 0 & 0 & 30 \\
\hline 9 & 0 & 0 & 0 & 0 & 30 & 0 & 0 & 0 & 0 & 30 \\
\hline 10 & 0 & 0 & 0 & 0 & 30 & 0 & 0 & 0 & 0 & 30 \\
\hline 11 & 10 & 0 & 0 & 10 & 30 & 10 & 0 & 10 & 0 & 40 \\
\hline 12 & 20 & 10 & 10 & 20 & 30 & 10 & 0 & 10 & 0 & 40 \\
\hline 13 & 30 & 20 & 20 & 20 & 40 & 10 & 0 & 20 & 0 & 40 \\
\hline 14 & 40 & 30 & 30 & 30 & 40 & 0 & 0 & 20 & 0 & 40 \\
\hline 15 & 40 & 40 & 40 & 40 & 40 & 10 & 0 & 30 & 30 & 40 \\
\hline 16 & 40 & 40 & 40 & 40 & 40 & 10 & 0 & 40 & 30 & 40 \\
\hline 17 & 40 & 40 & 40 & 40 & 40 & 10 & 10 & 40 & 30 & 40 \\
\hline 18 & 40 & 40 & 40 & 40 & 40 & 10 & 10 & 40 & 40 & 40 \\
\hline 19 & 40 & 40 & 40 & 40 & 40 & 0 & 10 & 40 & 40 & 40 \\
\hline 20 & 0 & 40 & 40 & 0 & 40 & 10 & 10 & 40 & 40 & 40 \\
\hline 21 & 40 & 40 & 40 & 30 & 30 & 10 & 20 & 40 & 10 & 40 \\
\hline 22 & 40 & 40 & 40 & 40 & 40 & 20 & 20 & 40 & 40 & 40 \\
\hline 23 & 40 & 40 & 40 & 40 & 40 & 30 & 30 & 40 & 40 & 40 \\
\hline 24 & 40 & 40 & 40 & 40 & 40 & 40 & 40 & 40 & 40 & 40 \\
\hline 25 & 40 & 40 & 40 & 40 & 40 & 40 & 40 & 40 & 40 & 40 \\
\hline 26 & 40 & 40 & 40 & 40 & 40 & 40 & 40 & 40 & 40 & 40 \\
\hline 27 & 40 & 40 & 40 & 40 & 40 & 30 & 40 & 40 & 40 & 30 \\
\hline 28 & 40 & 40 & 40 & 40 & 40 & 30 & 40 & 40 & 40 & 30 \\
\hline 29 & 40 & 40 & 40 & 0 & 40 & 30 & 40 & 40 & 40 & 30 \\
\hline 30 & 10 & & 40 & 0 & 40 & 30 & 40 & 40 & 40 & 30 \\
\hline
\end{tabular}


Table B.3

Firm by Firm Summaries, Cell $3(\mathrm{~B}=6 / \mathrm{B}=8 / \mathrm{B}=8)$

\begin{tabular}{|c|c|c|c|c|c|c|c|c|c|c|}
\hline Firm & 21 & 22 & 23 & 24 & 25 & 26 & 27 & 28 & 29 & 30 \\
\hline Barcelona & 0 & 0 & 0 & 0 & 0 & 1 & 1 & 1 & 1 & 1 \\
\hline Corrupt & 0 & 0 & 0 & 0 & 0 & 0 & 0 & 0 & 0 & 0 \\
\hline \multicolumn{11}{|l|}{ Round } \\
\hline 1 & 10 & 0 & 10 & 0 & 0 & 10 & 0 & 0 & 0 & 30 \\
\hline 2 & 10 & 0 & 0 & 10 & 0 & 10 & 0 & 0 & 0 & 40 \\
\hline 3 & 10 & 0 & 0 & 10 & 0 & 10 & 0 & 0 & 0 & 40 \\
\hline 4 & 10 & 10 & 0 & 10 & 0 & 20 & 0 & 0 & 0 & 40 \\
\hline 5 & 20 & 10 & 0 & 10 & 0 & 20 & 0 & 0 & 0 & 40 \\
\hline 6 & 20 & 20 & 0 & 10 & 0 & 30 & 0 & 0 & 0 & 40 \\
\hline 7 & 20 & 20 & 0 & 10 & 0 & 30 & 0 & 0 & 0 & 40 \\
\hline 8 & 20 & 30 & 0 & 0 & 0 & 30 & 0 & 0 & 0 & 40 \\
\hline 9 & 20 & 30 & 0 & 10 & 0 & 30 & 0 & 0 & 0 & 40 \\
\hline 10 & 20 & 40 & 0 & 0 & 0 & 20 & 0 & 0 & 0 & 40 \\
\hline 11 & 20 & 40 & 10 & 0 & 0 & 10 & 20 & 20 & 0 & 40 \\
\hline 12 & 30 & 40 & 20 & 0 & 0 & 20 & 40 & 30 & 0 & 40 \\
\hline 13 & 40 & 40 & 0 & 0 & 0 & 20 & 40 & 40 & 0 & 40 \\
\hline 14 & 40 & 40 & 40 & 10 & 40 & 30 & 40 & 40 & 0 & 40 \\
\hline 15 & 40 & 40 & 40 & 0 & 40 & 30 & 40 & 40 & 0 & 40 \\
\hline 16 & 40 & 40 & 40 & 0 & 40 & 40 & 40 & 40 & 0 & 40 \\
\hline 17 & 40 & 40 & 40 & 0 & 40 & 30 & 40 & 40 & 0 & 40 \\
\hline 18 & 40 & 40 & 40 & 0 & 40 & 30 & 40 & 40 & 0 & 40 \\
\hline 19 & 40 & 40 & 40 & 0 & 40 & 30 & 40 & 40 & 0 & 40 \\
\hline 20 & 40 & 40 & 40 & 0 & 40 & 30 & 40 & 40 & 0 & 40 \\
\hline 21 & 40 & 40 & 40 & 0 & 40 & 10 & 40 & 40 & 0 & 40 \\
\hline 22 & 40 & 40 & 40 & 0 & 40 & 10 & 40 & 40 & 0 & 40 \\
\hline 23 & 40 & 40 & 40 & 0 & 40 & 0 & 40 & 40 & 0 & 40 \\
\hline 24 & 40 & 40 & 40 & 0 & 40 & 0 & 40 & 40 & 0 & 40 \\
\hline 25 & 40 & 40 & 40 & 0 & 40 & 0 & 40 & 40 & 0 & 40 \\
\hline 26 & 40 & 40 & 40 & 0 & 40 & 0 & 40 & 40 & 0 & 40 \\
\hline 27 & 40 & 40 & 40 & 0 & 40 & 10 & 40 & 40 & 0 & 40 \\
\hline 28 & 40 & 40 & 40 & 0 & 40 & 20 & 40 & 40 & 0 & 40 \\
\hline 29 & 40 & 40 & 40 & 0 & 40 & 20 & 40 & 40 & 0 & 40 \\
\hline 30 & 40 & 40 & 40 & 0 & 40 & 30 & 0 & 40 & 0 & 40 \\
\hline
\end{tabular}


Table B.4

Firm by Firm Summaries, Cell $4(B=6 / B=14 / B=10)$

\begin{tabular}{|c|c|c|c|c|c|c|c|c|c|c|}
\hline Firm & 31 & 32 & 33 & 34 & 35 & 36 & 37 & 38 & 39 & 40 \\
\hline Barcelona & 0 & 0 & 0 & 0 & 0 & 1 & 1 & 1 & 1 & 1 \\
\hline Corrupt & 0 & 0 & 0 & 0 & 0 & 0 & 0 & 0 & 0 & 1 \\
\hline \multicolumn{11}{|l|}{ Round } \\
\hline 1 & 10 & 0 & 10 & 0 & 20 & 20 & 0 & 0 & 0 & 20 \\
\hline 2 & 0 & 10 & 10 & 0 & 0 & 0 & 0 & 20 & 0 & 40 \\
\hline 3 & 0 & 20 & 10 & 0 & 0 & 20 & 10 & 30 & 0 & 40 \\
\hline 4 & 0 & 10 & 10 & 0 & 0 & 0 & 10 & 20 & 0 & 40 \\
\hline 5 & 0 & 0 & 10 & 0 & 0 & 0 & 20 & 0 & 0 & 40 \\
\hline 6 & 0 & 0 & 10 & 0 & 0 & 0 & 0 & 0 & 0 & 40 \\
\hline 7 & 0 & 0 & 10 & 0 & 0 & 0 & 0 & 0 & 0 & 40 \\
\hline 8 & 0 & 0 & 10 & 0 & 0 & 0 & 0 & 0 & 0 & 40 \\
\hline 9 & 0 & 0 & 10 & 0 & 0 & 0 & 0 & 0 & 0 & 40 \\
\hline 10 & 0 & 0 & 10 & 0 & 0 & 0 & 0 & 0 & 0 & 40 \\
\hline 11 & 10 & 10 & 20 & 10 & 0 & 30 & 10 & 20 & 0 & 40 \\
\hline 12 & 0 & 0 & 30 & 10 & 0 & 30 & 10 & 20 & 0 & 40 \\
\hline 13 & 0 & 0 & 40 & 10 & 10 & 20 & 10 & 30 & 10 & 40 \\
\hline 14 & 10 & 0 & 40 & 20 & 10 & 30 & 20 & 30 & 20 & 10 \\
\hline 15 & 10 & 0 & 40 & 20 & 10 & 40 & 20 & 30 & 20 & 20 \\
\hline 16 & 10 & 0 & 40 & 30 & 10 & 30 & 20 & 20 & 20 & 10 \\
\hline 17 & 10 & 0 & 40 & 40 & 10 & 40 & 30 & 20 & 20 & 0 \\
\hline 18 & 10 & 0 & 40 & 40 & 10 & 20 & 30 & 20 & 30 & 20 \\
\hline 19 & 10 & 0 & 40 & 0 & 10 & 40 & 30 & 20 & 30 & 40 \\
\hline 20 & 20 & 0 & 40 & 0 & 20 & 40 & 30 & 30 & 30 & 20 \\
\hline 21 & 10 & 0 & 30 & 0 & 20 & 40 & 10 & 10 & 30 & 40 \\
\hline 22 & 20 & 0 & 40 & 10 & 20 & 40 & 20 & 30 & 40 & 40 \\
\hline 23 & 10 & 0 & 40 & 20 & 40 & 40 & 20 & 30 & 40 & 40 \\
\hline 24 & 40 & 0 & 40 & 30 & 40 & 40 & 20 & 30 & 40 & 40 \\
\hline 25 & 40 & 0 & 40 & 40 & 40 & 40 & 30 & 40 & 40 & 40 \\
\hline 26 & 40 & 0 & 40 & 40 & 40 & 40 & 30 & 40 & 40 & 40 \\
\hline 27 & 40 & 0 & 40 & 40 & 40 & 40 & 30 & 30 & 40 & 40 \\
\hline 28 & 40 & 0 & 40 & 40 & 40 & 40 & 30 & 40 & 40 & 40 \\
\hline 29 & 40 & 0 & 40 & 40 & 40 & 40 & 30 & 40 & 40 & 30 \\
\hline 30 & 40 & & 40 & 40 & 40 & 40 & 30 & 40 & 40 & 40 \\
\hline
\end{tabular}


Table B.5

Firm by Firm Summaries, Cell 5 (B = 6/B = 14/B = 6)

\begin{tabular}{|c|c|c|c|c|c|c|c|c|c|c|}
\hline Firm & 41 & 42 & 43 & 44 & 45 & 46 & 47 & 48 & 49 & 50 \\
\hline Barcelona & 0 & 0 & 0 & 0 & 0 & 1 & 1 & 1 & 1 & 1 \\
\hline Corrupt & 0 & 0 & 0 & 0 & 0 & 0 & 0 & 0 & 0 & 0 \\
\hline \multicolumn{11}{|l|}{ Round } \\
\hline 1 & 10 & 0 & 20 & 10 & 10 & 0 & 10 & 0 & 0 & 0 \\
\hline 2 & 10 & 0 & 10 & 20 & 0 & 0 & 10 & 0 & 0 & 0 \\
\hline 3 & 10 & 0 & 0 & 10 & 0 & 0 & 10 & 0 & 0 & 0 \\
\hline 4 & 0 & 0 & 0 & 10 & 0 & 0 & 0 & 0 & 0 & 0 \\
\hline 5 & 0 & 0 & 0 & 0 & 0 & 0 & 0 & 0 & 0 & 0 \\
\hline 6 & 0 & 0 & 0 & 0 & 0 & 0 & 0 & 0 & 0 & 0 \\
\hline 7 & 0 & 0 & 0 & 0 & 0 & 0 & 0 & 0 & 0 & 0 \\
\hline 8 & 0 & 10 & 0 & 0 & 0 & 0 & 0 & 0 & 0 & 0 \\
\hline 9 & 0 & 10 & 0 & 0 & 0 & 0 & 0 & 0 & 0 & 0 \\
\hline 10 & 0 & 20 & 0 & 0 & 0 & 0 & 0 & 0 & 0 & 0 \\
\hline 11 & 0 & 20 & 10 & 0 & 10 & 0 & 10 & 0 & 10 & 10 \\
\hline 12 & 0 & 20 & 40 & 20 & 20 & 10 & 20 & 0 & 20 & 10 \\
\hline 13 & 0 & 0 & 40 & 10 & 30 & 20 & 30 & 0 & 30 & 10 \\
\hline 14 & 0 & 0 & 40 & 30 & 40 & 20 & 0 & 0 & 40 & 10 \\
\hline 15 & 0 & 10 & 40 & 40 & 40 & 30 & 30 & 0 & 40 & 10 \\
\hline 16 & 0 & 0 & 40 & 40 & 40 & 40 & 30 & 0 & 40 & 10 \\
\hline 17 & 0 & 10 & 40 & 40 & 30 & 40 & 30 & 0 & 40 & 10 \\
\hline 18 & 0 & 20 & 40 & 40 & 30 & 40 & 30 & 0 & 40 & 10 \\
\hline 19 & 0 & 20 & 40 & 40 & 30 & 40 & 30 & 0 & 40 & 10 \\
\hline 20 & 0 & 30 & 40 & 40 & 30 & 40 & 30 & 0 & 40 & 10 \\
\hline 21 & 0 & 10 & 40 & 40 & 0 & 0 & 20 & 0 & 20 & 0 \\
\hline 22 & 0 & 20 & 40 & 40 & 0 & 0 & 20 & 0 & 20 & 0 \\
\hline 23 & 0 & 30 & 40 & 40 & 0 & 0 & 30 & 0 & 20 & 0 \\
\hline 24 & 0 & 30 & 40 & 40 & 0 & 0 & 30 & 0 & 20 & 0 \\
\hline 25 & 0 & 30 & 40 & 40 & 0 & 0 & 30 & 0 & 20 & 0 \\
\hline 26 & 0 & 30 & 40 & 40 & 0 & 0 & 30 & 0 & 20 & 0 \\
\hline 27 & 0 & 30 & 40 & 40 & 0 & 0 & 30 & 0 & 20 & 0 \\
\hline 28 & 0 & 30 & 40 & 40 & 0 & 0 & 30 & 0 & 20 & 0 \\
\hline 29 & 0 & 30 & 40 & 40 & 0 & 0 & 30 & 0 & 20 & 0 \\
\hline 30 & 0 & & 40 & 40 & 0 & 0 & 30 & 0 & 20 & 0 \\
\hline
\end{tabular}


Table B.6

Firm by Firm Summaries, Cell $6(B=6 / B=6 / B=14)$

\begin{tabular}{|c|c|c|c|c|c|c|c|c|c|c|}
\hline Firm & 51 & 52 & 53 & 54 & 55 & 56 & 57 & 58 & 59 & 60 \\
\hline Barcelona & 0 & 0 & 0 & 0 & 0 & 1 & 1 & 1 & 1 & 1 \\
\hline Corrupt & 0 & 0 & 0 & 0 & 0 & 0 & 0 & 0 & 0 & 0 \\
\hline \multicolumn{11}{|l|}{ Round } \\
\hline 1 & 0 & 20 & 0 & 0 & 10 & 10 & 0 & 0 & 0 & 20 \\
\hline 2 & 10 & 20 & 0 & 0 & 10 & 0 & 0 & 0 & 0 & 20 \\
\hline 3 & 0 & 10 & 0 & 0 & 10 & 0 & 0 & 0 & 0 & 20 \\
\hline 4 & 0 & 20 & 0 & 0 & 10 & 0 & 0 & 0 & 0 & 20 \\
\hline 5 & 0 & 20 & 0 & 0 & 10 & 0 & 0 & 0 & 0 & 20 \\
\hline 6 & 0 & 10 & 0 & 0 & 10 & 0 & 0 & 0 & 0 & 20 \\
\hline 7 & 0 & 0 & 0 & 0 & 10 & 0 & 0 & 0 & 0 & 20 \\
\hline 8 & 0 & 0 & 0 & 0 & 10 & 0 & 0 & 0 & 30 & 20 \\
\hline 9 & 0 & 0 & 0 & 0 & 10 & 0 & 0 & 0 & 30 & 20 \\
\hline 10 & 0 & 0 & 0 & 0 & 10 & 0 & 0 & 0 & 40 & 20 \\
\hline 11 & 0 & 0 & 0 & 0 & 10 & 0 & 0 & 0 & 40 & 20 \\
\hline 12 & 0 & 0 & 0 & 0 & 10 & 0 & 0 & 0 & 40 & 20 \\
\hline 13 & 0 & 0 & 0 & 0 & 10 & 0 & 0 & 0 & 40 & 20 \\
\hline 14 & 0 & 0 & 0 & 0 & 10 & 0 & 0 & 0 & 40 & 20 \\
\hline 15 & 0 & 0 & 0 & 0 & 10 & 0 & 0 & 0 & 40 & 20 \\
\hline 16 & 0 & 0 & 0 & 0 & 10 & 0 & 0 & 0 & 40 & 20 \\
\hline 17 & 0 & 0 & 0 & 0 & 10 & 0 & 0 & 0 & 40 & 20 \\
\hline 18 & 0 & 0 & 0 & 0 & 10 & 0 & 0 & 0 & 40 & 20 \\
\hline 19 & 0 & 0 & 0 & 0 & 10 & 0 & 0 & 0 & 40 & 20 \\
\hline 20 & 0 & 0 & 0 & 0 & 0 & 0 & 0 & 0 & 40 & 20 \\
\hline 21 & 10 & 0 & 10 & 10 & 10 & 0 & 10 & 0 & 40 & 20 \\
\hline 22 & 20 & 0 & 40 & 10 & 10 & 0 & 10 & 0 & 40 & 20 \\
\hline 23 & 30 & 0 & 40 & 10 & 10 & 0 & 30 & 0 & 40 & 20 \\
\hline 24 & 40 & 0 & 40 & 10 & 10 & 0 & 40 & 0 & 40 & 20 \\
\hline 25 & 40 & 0 & 40 & 10 & 10 & 0 & 40 & 0 & 40 & 10 \\
\hline 26 & 20 & 0 & 40 & 10 & 10 & 0 & 40 & 0 & 40 & 20 \\
\hline 27 & 20 & 0 & 40 & 10 & 10 & 0 & 40 & 0 & 40 & 20 \\
\hline 28 & 20 & 0 & 40 & 10 & 10 & 0 & 40 & 0 & 40 & 20 \\
\hline 29 & 20 & 0 & 40 & 10 & 10 & 0 & 40 & 0 & 40 & 20 \\
\hline 30 & 0 & & 40 & 10 & 0 & 0 & 40 & 0 & 40 & 20 \\
\hline
\end{tabular}


Table B.7

Ordered Probit Regressions Confirming Regularities 1 and 2 by Location

\begin{tabular}{|c|c|c|c|c|c|}
\hline \multicolumn{3}{|c|}{$\begin{array}{c}\text { Regularity } 1 \\
\text { Firm-level Data from Cells } 1-6 \text {, Rounds } 11-20\end{array}$} & \multicolumn{3}{|c|}{$\begin{array}{l}\text { Regularity 2 } \\
\text { Firm-level Data from Cells } 1,4 \text {, and 5, Rounds } 6-10 \text { and } 21-30\end{array}$} \\
\hline $\begin{array}{l}\text { Controls for } \\
\text { Individual Effects } \\
\end{array}$ & Clustering & $\begin{array}{l}\text { Random } \\
\text { Effects }\end{array}$ & $\begin{array}{c}\text { Controls for } \\
\text { Individual Effects } \\
\end{array}$ & Clustering & $\begin{array}{l}\text { Random } \\
\text { Effects }\end{array}$ \\
\hline Barcelona & $\begin{array}{l}.275 \\
(.415) \\
\end{array}$ & $\begin{array}{l}-.495 \\
(.597) \\
\end{array}$ & Barcelona & $\begin{array}{l}-.471^{* * *} \\
(.489) \\
\end{array}$ & $\begin{array}{l}-804^{* *} \\
(.331) \\
\end{array}$ \\
\hline Rounds $16-20$ & $\begin{array}{l}-.130 \\
(.443)\end{array}$ & $\begin{array}{l}-.196 \\
(.534)\end{array}$ & $\begin{array}{c}\text { Barcelona* } \\
\text { Rounds } 21-25, \text { Bonus }=6,10, \text { or } 14\end{array}$ & $\begin{array}{l}1.287^{* *} \\
(.588)\end{array}$ & $\begin{array}{c}2.438^{* * *} \\
(.419)\end{array}$ \\
\hline $\begin{array}{c}\text { Barcelona * } \\
\text { Rounds } 16-20\end{array}$ & .130 & $\begin{array}{l}.197 \\
(.740)\end{array}$ & $\begin{array}{c}\text { Barcelona* } \\
\text { Rounds } 26-30, \text { Bonus }=6,10, \text { or } 14\end{array}$ & $\begin{array}{l}1.322^{* *} \\
(.601)\end{array}$ & $\begin{array}{c}2.601^{* * *} \\
(.421)\end{array}$ \\
\hline $\begin{array}{c}\text { Barcelona* } \\
\text { Rounds } 11-15, \text { Bonus }=8,10, \text { or } 14\end{array}$ & $\begin{array}{c}1.139^{* * * *} \\
(.331)\end{array}$ & $\begin{array}{l}1.075^{* *} \\
(.513)\end{array}$ & $\begin{array}{c}\text { Barcelona* } \\
\text { Rounds } 21-25, \text { Bonus }=10 \text { or } 14\end{array}$ & $\begin{array}{c}.911 \\
(.572) \\
\end{array}$ & $\begin{array}{c}1.740^{* * *} \\
(.384)\end{array}$ \\
\hline $\begin{array}{c}\text { Barcelona* } \\
\text { Rounds } 16-20, \text { Bonus }=8,10, \text { or } 14\end{array}$ & $\begin{array}{c}1.872^{* * *} \\
(.335)\end{array}$ & $\begin{array}{c}2.763^{* * *} \\
(.546) \\
\end{array}$ & $\begin{array}{c}\text { Barcelona* } \\
\text { Rounds } 26-30, \text { Bonus }=10 \text { or } 14\end{array}$ & $\begin{array}{c}.826 \\
(.659) \\
\end{array}$ & $\begin{array}{c}1.531^{* * *} \\
(.385)\end{array}$ \\
\hline $\begin{array}{c}\text { Barcelona* } \\
\text { Rounds } 11-15, \text { Bonus }=14 \\
\end{array}$ & $\begin{array}{c}.353 \\
(.215) \\
\end{array}$ & $\begin{array}{l}.790^{* *} \\
(.356)\end{array}$ & $\begin{array}{c}\text { Cleveland* } \\
\text { Rounds } 21-25, \text { Bonus }=6,10 \text {, or } 14\end{array}$ & $\begin{array}{c}1.667^{* * * *} \\
(.640)\end{array}$ & $\begin{array}{c}4.038^{* * * *} \\
(.454)\end{array}$ \\
\hline $\begin{array}{c}\text { Barcelona* } \\
\text { Rounds } 16-20, \text { Bonus }=14\end{array}$ & $\begin{array}{l}-.132 \\
(.220)\end{array}$ & $\begin{array}{l}-.399 \\
(.403)\end{array}$ & $\begin{array}{c}\text { Cleveland } * \\
\text { Rounds } 26-30, \text { Bonus }=6,10, \text { or } 14\end{array}$ & $\begin{array}{l}1.703^{* *} \\
(.666)\end{array}$ & $\begin{array}{c}4.327^{* * *} \\
(.486) \\
\end{array}$ \\
\hline $\begin{array}{c}\text { Cleveland* } \\
\text { Rounds } 11-15, \text { Bonus }=8,10, \text { or } 14\end{array}$ & $\begin{array}{c}1.760^{* * *} \\
(.347)\end{array}$ & $\begin{array}{c}1.498^{* * *} \\
(.503)\end{array}$ & $\begin{array}{c}\text { Cleveland* } \\
\text { Rounds } 21-25, \text { Bonus }=10 \text { or } 14 \\
\end{array}$ & $\begin{array}{c}.006 \\
(.648) \\
\end{array}$ & $\begin{array}{l}.248 \\
(.391)\end{array}$ \\
\hline $\begin{array}{c}\text { Cleveland* } \\
\text { Rounds } 16-20, \text { Bonus }=8,10, \text { or } 14\end{array}$ & $\begin{array}{c}3.126^{* * *} \\
(.392)\end{array}$ & $\begin{array}{c}3.561^{* * *} \\
(.573)\end{array}$ & $\begin{array}{c}\text { Cleveland* } \\
\text { Rounds } 26-30, \text { Bonus }=10 \text { or } 14\end{array}$ & $\begin{array}{c}.396 \\
(.745)\end{array}$ & $\begin{array}{l}1.097^{* *} \\
(.451)\end{array}$ \\
\hline $\begin{array}{c}\text { Cleveland* } \\
\text { Rounds } 11-15, \text { Bonus }=14 \\
\end{array}$ & $\begin{array}{l}-.296 \\
(.209) \\
\end{array}$ & $\begin{array}{l}-.184 \\
(.443)\end{array}$ & $\begin{array}{c}\text { Minimum Effort } \\
\text { Round 5 } \\
\end{array}$ & $\begin{array}{l}.068^{* * *} \\
(.024)\end{array}$ & $\begin{array}{l}-.015^{*} \\
(.009) \\
\end{array}$ \\
\hline $\begin{array}{c}\text { Cleveland* } \\
\text { Rounds } 16-20, \text { Bonus }=14\end{array}$ & $\begin{array}{l}-1.126^{* * *} \\
(.252)\end{array}$ & $\begin{array}{c}-1.192^{* *} \\
(.466) \\
\end{array}$ & & & \\
\hline $\begin{array}{c}\text { Minimum Effort } \\
\text { Round } 10 \\
\end{array}$ & $\begin{array}{l}.066^{* * *} \\
(.006) \\
\end{array}$ & $\begin{array}{l}.157 \\
(.017) \\
\end{array}$ & & & \\
\hline Log Likelihood & -701.95 & $\begin{array}{l}-527.91 \\
\end{array}$ & Log Likelihood & -432.30 & -278.20 \\
\hline \# Observations & 580 & 580 & \# Observations & 429 & 429 \\
\hline
\end{tabular}

*** $\quad$ Significant at $1 \%$ level

** $\quad$ Significant at 5\% level

* $\quad$ Significant at $10 \%$ level 
Table B.8

Ordered Probit Regressions Confirming Regularities 1 and 2 with Alternative Time Controls

\begin{tabular}{|c|c|c|c|c|c|}
\hline \multicolumn{3}{|c|}{$\begin{array}{l}\text { Regularity } 1 \\
\text { Firm-level Data from Cells } 1-6, \text { Rounds } 11-20\end{array}$} & \multicolumn{3}{|c|}{$\begin{array}{c}\text { Regularity } 2 \\
\text { Firm-level Data from Cells } 1,4 \text {, and 5, Rounds } 6-10 \text { and } 21-30\end{array}$} \\
\hline $\begin{array}{c}\text { Controls for } \\
\text { Individual Effects }\end{array}$ & Clustering & $\begin{array}{l}\text { Random } \\
\text { Effects }\end{array}$ & $\begin{array}{c}\text { Controls for } \\
\text { Individual Effects } \\
\end{array}$ & Clustering & $\begin{array}{c}\text { Random } \\
\text { Effects }\end{array}$ \\
\hline $\mathrm{B}=8$ & $\begin{array}{c}2.547^{* * *} \\
(.693)\end{array}$ & $\begin{array}{c}4.107^{* * *} \\
(.628) \\
\end{array}$ & Rounds $21-30$ & $\begin{array}{c}1.388^{* * *} \\
(.425) \\
\end{array}$ & $\begin{array}{c}4.690^{* * *} \\
(.495)\end{array}$ \\
\hline $\mathrm{B}=10$ & $\begin{array}{c}3.066^{* * *} \\
(.576)\end{array}$ & $\begin{array}{c}4.159^{* * *} \\
(.559)\end{array}$ & $\begin{array}{l}\text { Rounds } 21-30 \\
* \mathrm{~B}=10\end{array}$ & $\begin{array}{c}.064 \\
(.496) \\
\end{array}$ & $\begin{array}{c}3.958^{* * *} \\
(.568)\end{array}$ \\
\hline$B=14$ & $\begin{array}{c}2.040^{* * *} \\
(.370)\end{array}$ & $\begin{array}{c}2.808^{* * *} \\
(.453) \\
\end{array}$ & $\begin{array}{c}\text { Rounds } 21-30 \\
* \mathrm{~B}=14 \\
\end{array}$ & $\begin{array}{l}.565 \\
(.506) \\
\end{array}$ & $\begin{array}{c}-1.244^{* * *} \\
(.431) \\
\end{array}$ \\
\hline 20 - Round & $\begin{array}{c}.014 \\
(.012)\end{array}$ & $\begin{array}{c}.029 \\
(.070)\end{array}$ & $\begin{array}{l}30-\text { Round (if Round }>20 \text { ) } \\
10-\text { Round (if Round } \leq 10 \text { ) }\end{array}$ & $\begin{array}{l}-.051 \\
(.047)\end{array}$ & $\begin{array}{l}-.099 \\
(.104)\end{array}$ \\
\hline $\begin{array}{l}(20-\text { Round }) \\
* \mathrm{~B}=8\end{array}$ & $\begin{array}{l}-156^{* * *} \\
(.060)\end{array}$ & $\begin{array}{l}-.386^{* * *} \\
(.099)\end{array}$ & $(30-$ Round) $*$ Rounds $21-30$ & $\begin{array}{c}.043 \\
(.045)\end{array}$ & $\begin{array}{c}.017 \\
(.111)\end{array}$ \\
\hline $\begin{array}{c}(20-\text { Round }) \\
* \mathrm{~B}=10\end{array}$ & $\begin{array}{l}-.228^{* * * *} \\
(.070)\end{array}$ & $\begin{array}{l}-.371^{* * * *} \\
(.085) \\
\end{array}$ & $\begin{array}{c}(30-\text { Round }) * \text { Rounds } 21-30 \\
* \mathrm{~B}=10\end{array}$ & $\begin{array}{l}-158^{* * *} \\
(.055) \\
\end{array}$ & $\begin{array}{l}-.426^{* * *} \\
(.090) \\
\end{array}$ \\
\hline $\begin{array}{c}(20-\text { Round }) \\
* \mathrm{~B}=14\end{array}$ & $\begin{array}{l}-.082^{* * *} \\
(.029)\end{array}$ & $\begin{array}{l}-.174^{* *} \\
(.075)\end{array}$ & $\begin{array}{c}(30-\text { Round) } * \text { Rounds } 21-30 \\
* \mathrm{~B}=14\end{array}$ & $\begin{array}{l}.073^{*} \\
(.041)\end{array}$ & $\begin{array}{l}.254^{* * *} \\
(.079)\end{array}$ \\
\hline Barcelona & $\begin{array}{l}-.011 \\
(.264)\end{array}$ & $\begin{array}{l}-.303 \\
(.223)\end{array}$ & Barcelona & $\begin{array}{l}-.464 \\
(.381)\end{array}$ & $\begin{array}{l}-1.957^{* * * *} \\
(.235)\end{array}$ \\
\hline $\begin{array}{l}\text { Minimum Effort } \\
\text { Round } 10\end{array}$ & $\begin{array}{l}.068^{* * *} \\
(.016)\end{array}$ & $\begin{array}{l}.162^{* * *} \\
(.015)\end{array}$ & $\begin{array}{l}\text { Minimum Effort } \\
\text { Round } 5\end{array}$ & $\begin{array}{l}.071^{* * *} \\
(.025)\end{array}$ & $\begin{array}{c}.015 \\
(.010)\end{array}$ \\
\hline Log Likelihood & -704.30 & -513.41 & Log Likelihood & -421.21 & -247.91 \\
\hline \# Observations & 580 & 580 & \# Observations & 429 & 429 \\
\hline
\end{tabular}

*** $\quad$ Significant at $1 \%$ level

** $\quad$ Significant at $5 \%$ level

* $\quad$ Significant at $10 \%$ level 
Table C.1

Parameter Estimates for Learning Models

\begin{tabular}{|c|c|c|}
\hline Variable & Basic EWA & EWA w/ Strategic Teaching \\
\hline $\begin{array}{c}\text { Initial Attraction } \\
\text { Effort Level } 0\left(\mathrm{~A}^{0}(0) / 100\right)\end{array}$ & $\begin{array}{c}1.109 \\
(1.453) \\
\end{array}$ & $\begin{array}{c}1.114 \\
(1.564) \\
\end{array}$ \\
\hline $\begin{array}{c}\text { Initial Attraction } \\
\text { Effort Level } 10\left(\mathrm{~A}^{10}(0) / 100\right)\end{array}$ & $\begin{array}{c}1.100 \\
(1.443)\end{array}$ & $\begin{array}{c}1.092 \\
(1.564) \\
\end{array}$ \\
\hline $\begin{array}{c}\text { Initial Attraction } \\
\text { Effort Level } 20\left(\mathrm{~A}^{20}(0) / 100\right)\end{array}$ & $\begin{array}{l}1.116 \\
(1.462)\end{array}$ & $\begin{array}{c}1.126 \\
(1.564) \\
\end{array}$ \\
\hline $\begin{array}{c}\text { Initial Attraction } \\
\text { Effort Level } 30\left(\mathrm{~A}^{30}(0) / 100\right)\end{array}$ & $\begin{array}{c}1.092 \\
(1.431) \\
\end{array}$ & $\begin{array}{c}1.085 \\
(1.564) \\
\end{array}$ \\
\hline $\begin{array}{c}\text { Initial Attraction } \\
\text { Effort Level } 40\left(\mathrm{~A}^{40}(0) / 100\right)\end{array}$ & $\begin{array}{c}1.131 \\
(1.480)\end{array}$ & $\begin{array}{c}1.172 \\
(1.565) \\
\end{array}$ \\
\hline Forgetting $(\varphi)$ & $\begin{array}{l}.520^{* * *} \\
(.034)\end{array}$ & $\begin{array}{l}.543^{* * *} \\
(.034)\end{array}$ \\
\hline Depreciation $(\rho)$ & $\begin{array}{l}.906^{* * *} \\
(.114)\end{array}$ & $\begin{array}{l}.822^{* * *} \\
(.101)\end{array}$ \\
\hline Imagination $(\delta)$ & $\begin{array}{l}.434^{* * *} \\
(.024)\end{array}$ & $\begin{array}{l}.457^{* * *} \\
(.026)\end{array}$ \\
\hline Sensitivity $(1 / 10 \lambda)$ & $\begin{array}{l}.520^{* * * *} \\
(.034)\end{array}$ & $\begin{array}{l}1.117 \\
(.737) \\
\end{array}$ \\
\hline $\begin{array}{c}\text { Strength of } \\
\text { Initial Attractions }(\mathrm{N}(0) / 10)\end{array}$ & $\begin{array}{c}2.122 \\
(3.468) \\
\end{array}$ & $\begin{array}{l}9.876^{*} \\
(5.634) \\
\end{array}$ \\
\hline Reset Parameter $\left(\mathrm{r}_{10}\right)$ & $\begin{array}{l}.416^{* * *} \\
(.077)\end{array}$ & $\begin{array}{l}.381^{* * *} \\
(.071)\end{array}$ \\
\hline $\begin{array}{c}\text { Positive Change } \\
\text { Sensitivity }\left(1000 \mathrm{C}^{+}\right)\end{array}$ & & $\begin{array}{l}-9.573^{* * *} \\
(3.362) \\
\end{array}$ \\
\hline $\begin{array}{c}\text { Negative Change } \\
\text { Sensitivity }\left(1000 \mathrm{C}^{-}\right)\end{array}$ & & $\begin{array}{c}.686 \\
(3.570) \\
\end{array}$ \\
\hline $\begin{array}{c}\text { Probability } \\
\text { Strategic Teacher }\end{array}$ & & $\begin{array}{l}.074^{*} \\
(.042)\end{array}$ \\
\hline $\begin{array}{c}\text { Sensitivity } \\
\text { Strategic Teachers }\left(1 / 10 \lambda_{\mathrm{f}}\right)\end{array}$ & & $\begin{array}{c}3.784 \\
(5.014) \\
\end{array}$ \\
\hline $\begin{array}{c}\text { Weight on } \\
\text { Forward Payoffs }\left(\mathrm{w}_{\mathrm{F}}\right)\end{array}$ & & $\begin{array}{c}4.028 \\
(6.875) \\
\end{array}$ \\
\hline Log Likelihood & -2584.63 & -2573.69 \\
\hline
\end{tabular}

Significant at $1 \%$ level

** $\quad$ Significant at 5\% level

* $\quad$ Significant at $10 \%$ level 


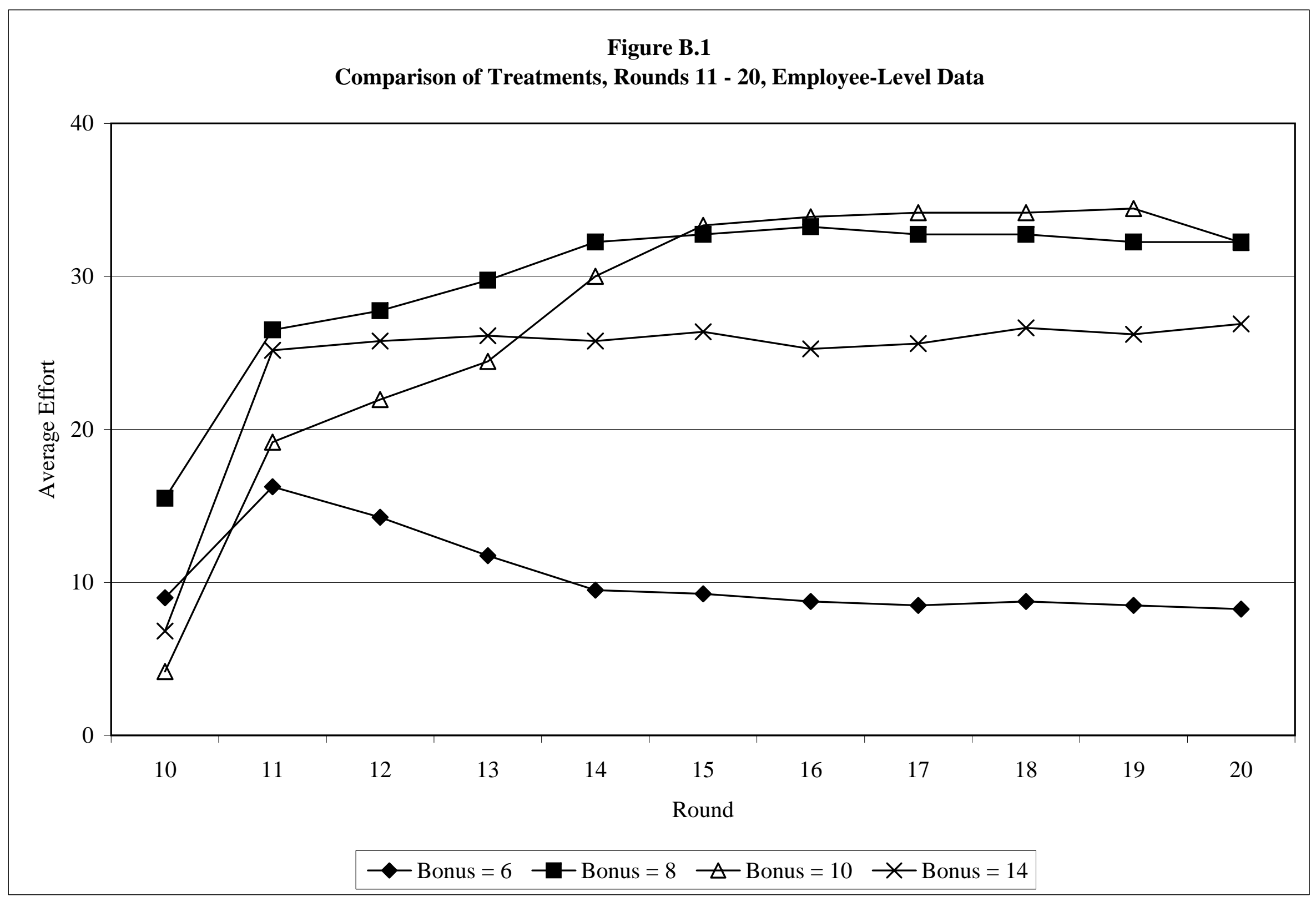




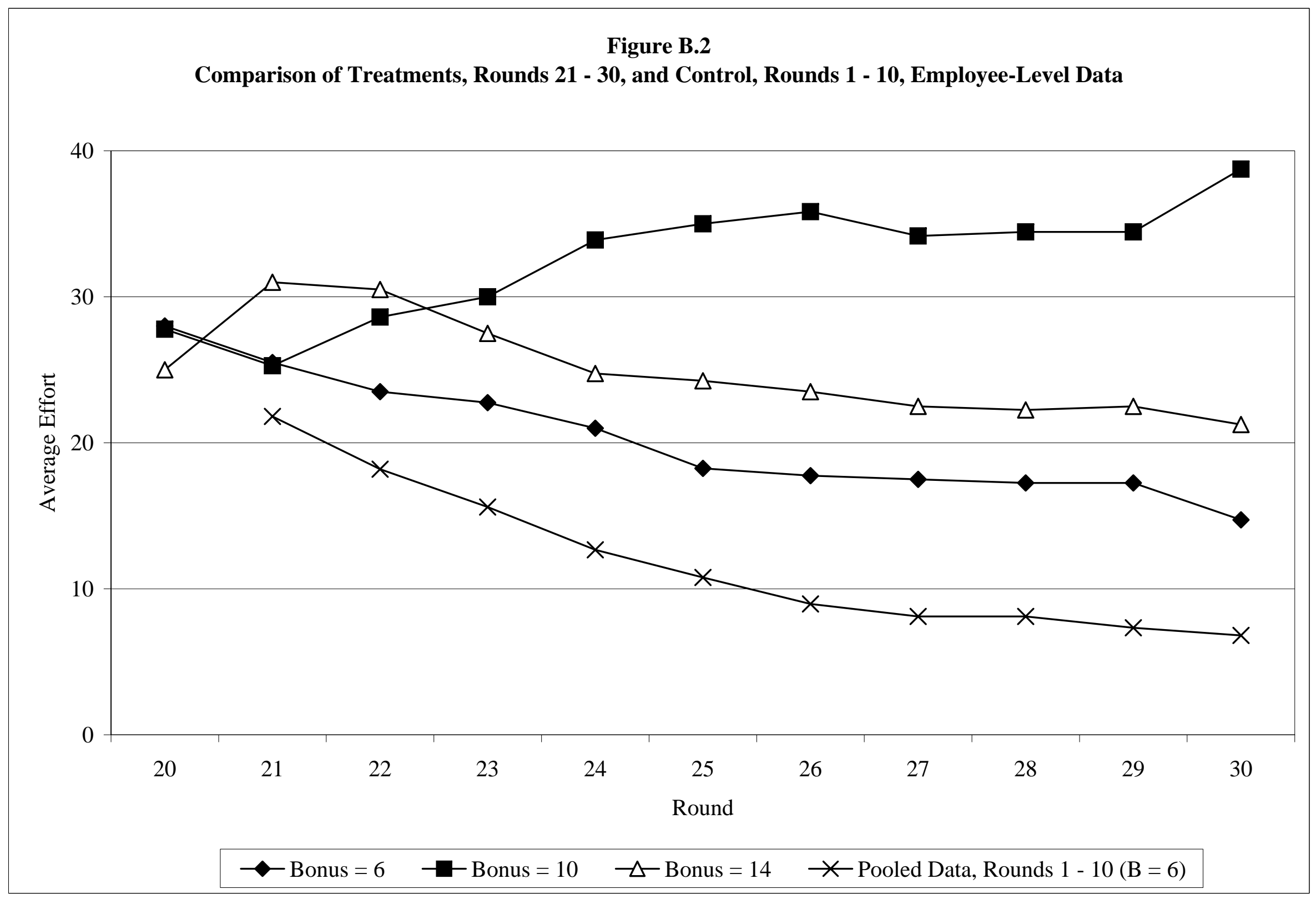




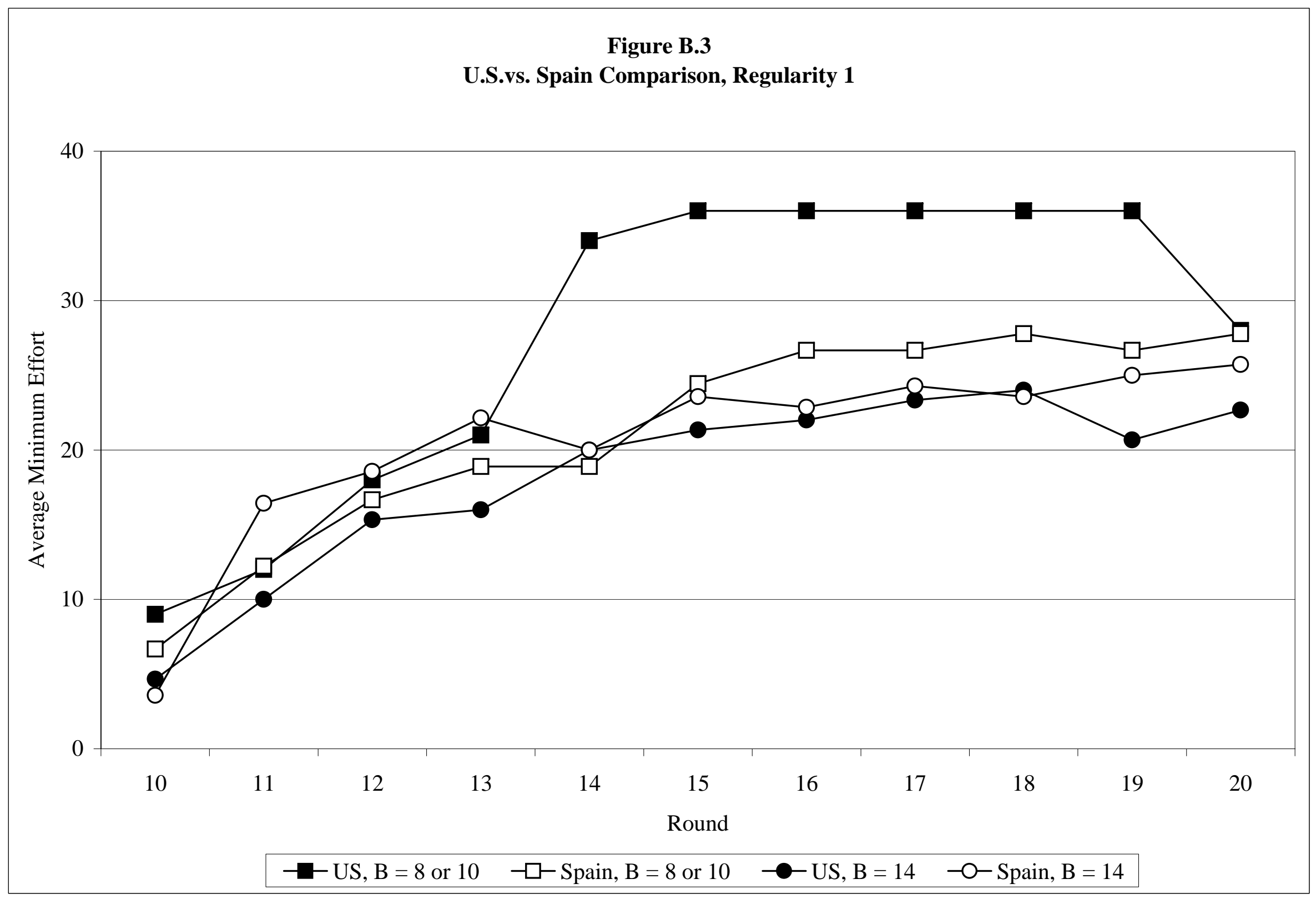




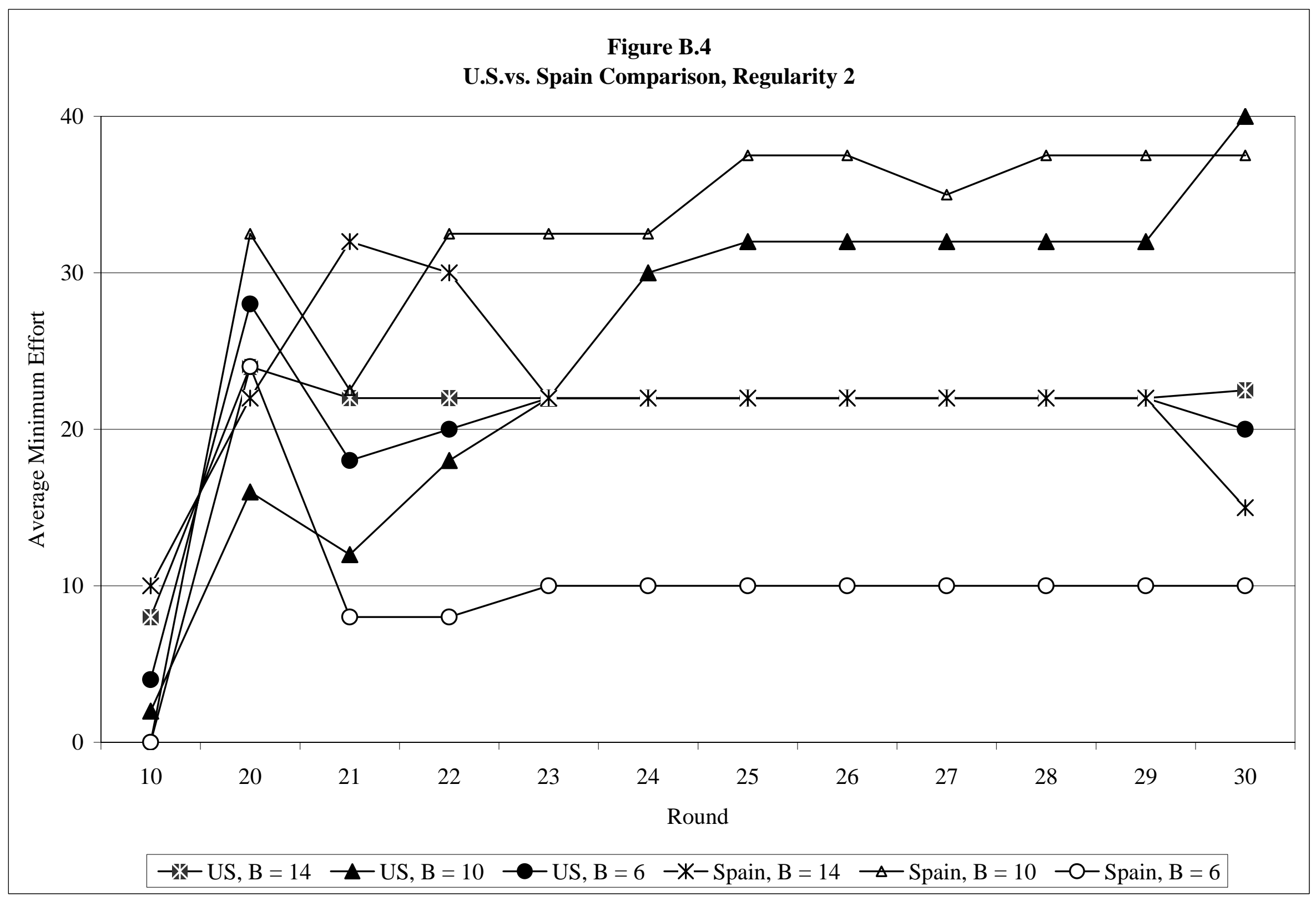

